\title{
BIOLOGICAL CONTROL ON ACID GENERATION AT THE CONDUIT-BEDROCK BOUNDARY IN SUBMERGED CAVES: QUANTIFICATION THROUGH GEOCHEMICAL MODELING
}

\author{
VPLIV BIOLOŠKIH PROCESOV NA IZVOR KISLIN OB MEJI MED \\ KRAŠKIM PREVODNIKOM IN MATIČNO KAMNINO V ZALITI \\ CONI: KVANTITATIVNA OCENA NA OSNOVI GEOKEMIČNEGA \\ MODELIRANJA
}

\author{
Janet S. HERMAN ${ }^{1 *}$, Alexandria G. HOUNSHELL ${ }^{1}$, Rima B. FRANKLIN ${ }^{2}$ \& Aaron L. MILLS ${ }^{1}$
}

\begin{abstract}
UDC UDK:550.46:551.444

Janet S. Herman, Alexandria G. Hounshell, Rima B. Franklin \& Aaron L. Mills: Biological Control on Acid Generation at the Conduit-Bedrock Boundary in Submerged Caves: Quantification through Geochemical Modeling

No-mount Cave, located in Wekiwa Springs State Park in central Florida, USA, is an aphotic, submerged, freshwater cave in which large colonies of sulfur-oxidizing bacteria live in filamentous microbial mats. Upwardly discharging groundwater enters the cave from the Upper Floridan aquifer, specifically the Eocene-aged Ocala Limestone. We undertook a combined field, laboratory, and modeling study in which we sought to determine the amount of calcite dissolution attributable to the generation of protons by microbially mediated sulfide oxidation. The chemical compositions of groundwater within the limestone formation collected through a newly designed sampling device and of water in the cave conduit were used in geochemical modeling. We used the reaction-path model PHREEQCI to quantify the amount of calcite dissolution expected under various plausible scenarios for mixing of formation water with conduit water and extent of bacterial sulfide oxidation. Laboratory experiments were conducted using flow-through columns packed with crushed limestone from the study site. Replicate columns were eluted with artificial groundwater containing dissolved HS in the absence of microbial growth. Without biologically mediated sulfide oxidation, no measurable calcite dissolution occurred in laboratory experiments and no additional amount of speleogenesis is expected as formation water mixes with conduit water in the field. In contrast, significant calcite dissolution is driven by the protons released in the biological transformation of the aqueous sulfur species. Although a range of results were calculated, a plausible amount of $158 \mathrm{mg} \mathrm{Ca}{ }^{2+}$ released to conduit water per liter of groundwater crossing the formation-conduit boundary and mixing with an equal volume
\end{abstract}

Izvleček

UDK UDK:550.46:551.444

Janet S. Herman, Alexandria G. Hounshell, Rima B. Franklin \& Aaron L. Mills: Vpliv bioloških procesov na izvor kislin ob meji med kraškim prevodnikom in matično kamnino $v$ zaliti coni: kvantitativna ocena na osnovi geokemičnega modeliranja

Jama No-mount je zalita sladkovodna jama v državnem parku Wekiva Springs, Florida, ZDA. Skozi jamo se proti površju pretaka voda iz Zgornjega Floridskega apnenčastega vodonosnika eocenske starosti. V afotičnem okolju jame so kolonije oksidirajočih bakterij v obliki vlaknastih skupkov. $\mathrm{Na}$ osnovi terenskih, laboratorijskih in modelskih raziskav smo ocenjevali možen speleogenetski pomen bakterijske oksidacije sulfidov. Ocenjevali smo raztapljanje kalcita v različnih scenarijih mešanja vode iz apnenčaste matrice in jamske vode ob prisotnosti oksidacije sulfida. Pri geokemičnem modeliranju smo uporabili modul reakcijskih poti v modelskem okolju PHREEQCI, kot vhodni podatek modela smo vzeli sestavo vode iz matrice in jamskega rova. Za vzorčenje vode $\mathrm{v}$ matrici apnenca smo v okviru te raziskave razvili nov vzorčevalnik. Laboratorijske raziskave so temeljile na pretočnem reaktorju, pri čemer smo $\mathrm{v}$ reaktorskem stolpcu uporabili zdrobljen apnenec $\mathrm{Z}$ mesta raziskav in $\mathrm{v}$ njem mešali laboratorijske replike vode porozne matrice obogatene s sulfidom in jamske vode $\mathrm{z}$ dodanim kisikom. Ob odsotnosti biološke aktivnosti ni bilo raztapljanja ob mešanje matrične in jamske vode. Do občutnega raztapljanja pa je prišlo ob dovajanju protonov, ki se sprostijo pri biološki pretvorbi v vodi raztopljenih žveplovih spojin. Iz širšega spektra rezultatov smo izluščili relevantno vrednost. Ocenili smo, da se v jamsko vodo sprosti $158 \mathrm{mg}$ kalcija na vsak liter vode, ki iz porozne matrice preide $\mathrm{v}$ jamski rov in se meša $\mathrm{z}$ jamsko

\footnotetext{
${ }^{1}$ Department of Environmental Sciences, University of Virginia, P.O. Box 400123, Charlottesville, VA 22904-4123

${ }^{2}$ Department of Biology, Virginia Commonwealth University, 1000 West Cary Street, Room 126, Richmond, VA $23284-2012$

*Corresponding Author, e-mail: jherman@virginia.edu

Received/Prejeto: 1.2.2013
} 
of conduit water was predicted. Our modeling results indicate that significant cave development can be driven by microbially mediated sulfide oxidation under these hydrogeochemical conditions.

Keywords: calcite dissolution, microbial sulfide oxidation, geochemical model. vodo v enakem razmerju. Naš model kaže, da lahko mikrobsko pogojena oksidacija sulfidov pomembno vpliva na speleogenezo $\mathrm{v}$ pogojih podobnih našim.

Ključne besede: raztapljanje kalcita, mikrobska oksidacija sulfidov, geokemični model.

\section{INTRODUCTION}

Hypogenic cave communities, devoid of any light and based on energy produced by chemoautotrophs, have been described in environments ranging from submarine caves in Italy to large caverns in Mexico (Bottrell et al. 1991; Hose et al. 2000; Mattison et al. 1998; Sarbu et al. 1996; Vlasceanu et al. 2000). In each cave, microbial mats were observed in areas with high hydrogen sulfide concentrations, and sulfide oxidation to elemental sulfur or to sulfate is the energy source for carbon fixation into biomass. Mats of sulfur-oxidizing bacteria can occur along the water-atmosphere interface in cave pools and streams (e.g., Hubbard et al. 1986) or, more commonly, at the interface between the cave conduit and the limestone cave walls where sulfide-rich groundwater seeps through the bedrock (Mattison et al. 1998). The biogeochemical reactions carried out by sulfur-oxidizing bacteria could have a significant effect on limestone dissolution and cave enlargement (Engel \& Randall, 2011; Hose et al. 2000; Macalady et al. 2006; Sarbu et al. 1996; Vlasceanu et al. 2000).

Calcite, the main reactive mineral in limestone, is dissolved in the presence of $\mathrm{H}^{+}$ions in solution and is, therefore, sensitive to the acidity of natural waters. The dissolution of $\mathrm{CO}_{2}$ gas to form carbonic acid in natural waters is the most common source of acid that dissolves calcite (White 1988). In an environment in which sulfide is undergoing oxidation, however, there is another significant source of acid. One of the products of sulfur oxidation (Eqns. 1 and 2) is sulfuric acid which ultimately dissociates to $\mathrm{H}^{+}$ions in aqueous solutions (Erlich \& Newman 2009).

$$
\begin{aligned}
& \mathrm{H}_{2} \mathrm{~S}(\mathrm{aq})+1 / 2 \mathrm{O}_{2}(\mathrm{~g}) \leftrightarrows \mathrm{S}^{0}(\mathrm{~s})+\mathrm{H}_{2} \mathrm{O} \\
& \mathrm{S}^{0}(\mathrm{~s})+1 \frac{1 / 2}{} \mathrm{O}_{2}(\mathrm{~g})+\mathrm{H}_{2} \mathrm{O} \leftrightarrows 2 \mathrm{H}^{+}+\mathrm{SO}_{4}^{2-}
\end{aligned}
$$

Due to the production of acid, an increase in calcite dissolution (Eqn. 3) is expected when sulfide oxidation, either biotic or abiotic, is present.

$$
\mathrm{CaCO}_{3}(\mathrm{~s})+\mathrm{H}^{+} \leftrightarrows \mathrm{Ca}^{2+}+\mathrm{HCO}_{3}^{-}
$$

A recent study conducted in the sulfide-rich, saline portion of the karstic Edwards Aquifer in Central Texas found increased extent of calcite dissolution in the presence of sulfide-oxidizing bacteria when compared to abiotic calcite dissolution in situ (Engel \& Randall, 2011). The aquifer is developed in limestone and includes abundant, filamentous, microbial mats which were determined to contain sulfide-oxidizing bacteria along the limestone wall of the open-hole wells. Microcosms comprising calcite chips were suspended in wells, one treatment inoculated with sulfide-oxidizing bacteria and one that was not. The amount of dissolution was determined by weight loss of the calcite chips. The results were direct evidence of an increased extent of calcite dissolution due to sulfide-oxidizing bacteria in limestone aquifers.

The extent to which sulfuric-acid speleogenesis influences cave enlargement may be great, as indicated by the acidity of that environment. In several subaerial caves containing microbial mats, very low $\mathrm{pH}$ readings (between 0 and 1) were measured within the water droplets known as 'snottites' hanging from the mats (Hose et al. 2000; Sarbu et al. 1996), yet the cave streams remain near neutral indicating neutralization by calcite dissolution. Very few studies, however, have included quantification of the extent of calcite dissolution due to microbially mediated sulfide oxidation in cave development.

Most caves with abundant chemoautotrophic bacteria that have been studied to date were either subaerial or submerged by saline waters. Some freshwater-filled caves, however, have been shown to contain extensive microbial mats as well. One such setting, No-mount Cave feeding the Wekiwa Spring in central Florida, is the focus of the present study in which we seek to quantify the extent of calcite dissolution attributable to sulfide-oxidizing bacteria. Our conceptual model of the geochemical conditions leading to speleogenesis is illustrated in Fig. 1, in which sulfide-containing groundwater within the limestone formation enters a cave conduit through a bacterial mat covering the cave walls. We believe that sulfide oxidation is occurring at the base of the bacterial mat near the cave wall, where the exceptionally soft texture of the limestone is in sharp contrast with the harder, 


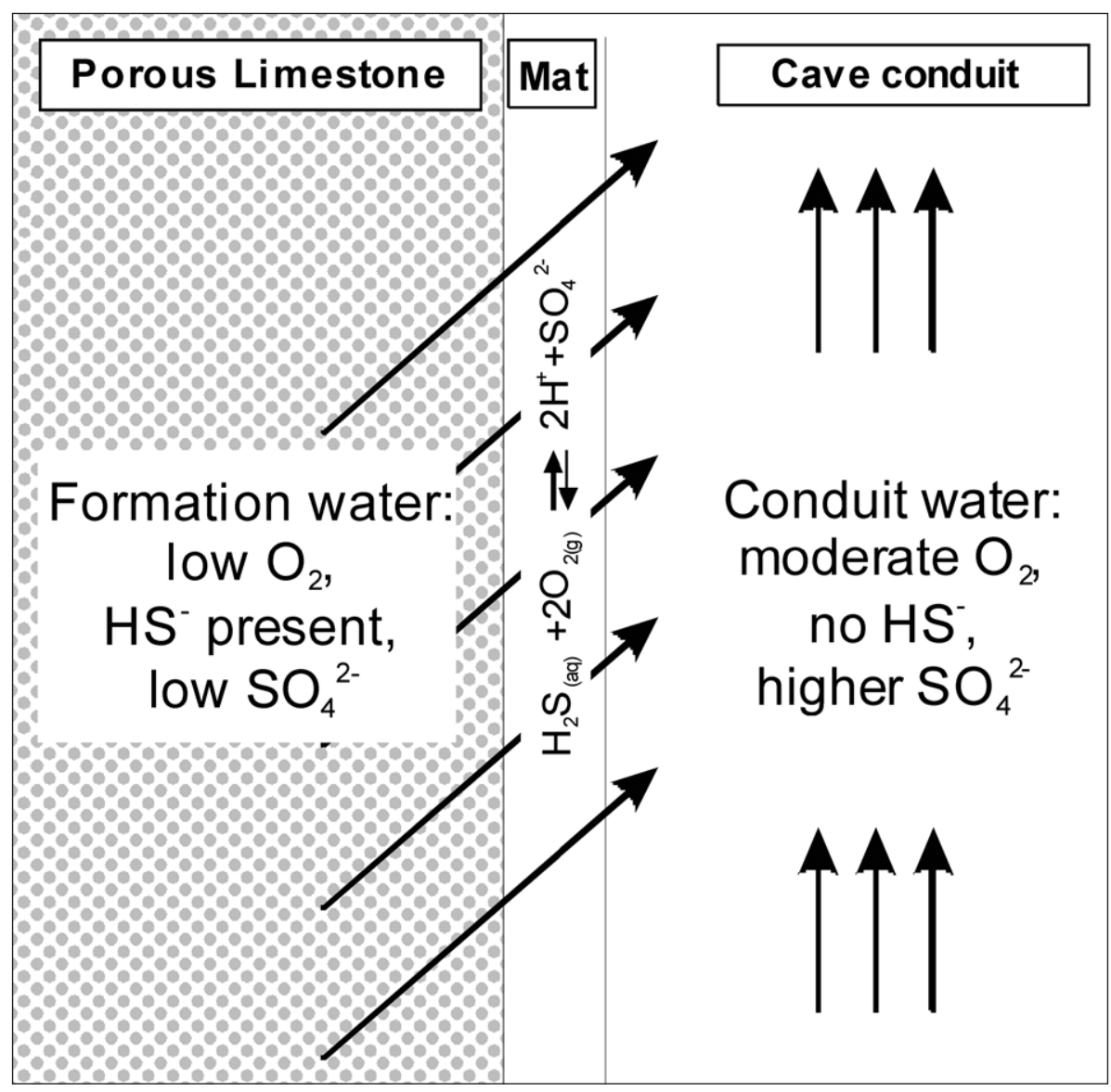

Fig. 1: In our conceptual model of the field situation, groundwater (herein termed formation water) containing dissolved reduced sulfur (depicted here as $\mathrm{HS}^{-}$) passes from the porous limestone rock walls of the cave where it is acted upon by sulfur-oxidizing microbes in the abundant mats growing on the cave walls. In the presence of dissolved oxygen from the conduit water, the bacteria oxidize the sulfide releasing $\mathrm{SO}_{4}^{2-}$ and protons which then can accelerate the dissolution of the limestone at the cave wall.

more competent limestone that is not covered in bacterial mat. A simulation of abiotic dissolution was carried out experimentally in laboratory experiments, and the extents of abiotic and of bacterially mediated calcite dissolution were modeled using a geochemical reactionpath model constrained by dissolved ion concentrations observed in the field and in the laboratory.

\section{METHODS}

\section{FIELD SITE}

Groundwater of the Upper Floridan aquifer discharges at Wekiwa Springs located in Wekiwa Springs State Park, near Apopka (28 $8^{\circ} 42^{\prime} 42.79^{\prime}$ N N, 81 $27^{\prime} 37.52^{\prime \prime} \mathrm{W}$ ) north of Orlando, Florida, USA (Ferguson et al. 1947). The spring discharge is derived from two observed features: a vertical shaft and a horizontal cavern, both of which are disconnected from surface recharge features. The main boil is essentially a vertical shaft (down to at least $20 \mathrm{~m}$, the maximum depth reached by this research team) and is responsible for the majority of the total discharge from Wekiwa Springs. This flow combines with discharge from a smaller horizontal vent (approximately $4.2 \times 0.6 \mathrm{~m}$ ) lo- cated about $5 \mathrm{~m}$ below the water surface, which serves as the entrance to "No-mount" Cave. The term "no mount" refers to the dive-gear configuration required to access the cave passage.

No-mount Cave is developed in bedrock of the Ocala Limestone, an Eocene-aged formation of predominantly limestone and occasional dolostone layers that is confined by the overlying Hawthorn Formation composed mostly of lower permeability clay, silt, and sand beds (Miller 1986). The upper facies of the Ocala Limestone is poorly indurated fossiliferous limestone (Scott 1991) and is an important, highly conductive component of the Floridan Aquifer System (Miller 1990). 
The submerged entrance of the cave lies along a horizontal bedding plane near the bottom of the spring basin. There is a small photic zone at the entrance followed by a narrow opening into a larger $(5 \times 2 \times 2 \mathrm{~m})$ aphotic cavern that penetrates down into the limestone bedrock at a small angle off vertical. The ceiling and walls of the aphotic cavern are covered by filamentous microbial mats with long white streamers that often extend $5-10 \mathrm{~cm}$ from the rock surface and that support an ecosystem of small invertebrates (Franklin et al. 2005). Similar mats have been observed in all areas of No-mount Cave that have thus far been explored and can also be found in sporadic locations in the shaft of the nearby main boil. Greatest biomass accumulation is observed in sheltered areas and crevices with low flow turbulence.

The microbial mats are dominated by sulfur-oxidizing bacteria (Franklin et al. 2011; Hill \& Franklin 2012). Initially, the nature of the bacteria was confirmed visually by the presence of sulfur granules within these bacterial cells using phase-contrast microcopy. Subsequently, molecular genetic analyses have been conducted using whole-community DNA extracted from the mat samples. Cloning and sequencing of the 16S-rRNA gene has demonstrated the presence of several groups of sulfuroxidizing bacteria including: Thiobacillus, Thiospira, and Beggiatoa (Hill \& Franklin 2012).

\section{FIELD SAMPLING}

Water and microbial mat samples were collected from No-mount Cave on five dates: January 19 and July 15 2005, January 16 and July 7 2006, and July 23 2007. Samples were obtained by technical divers from the Cambrian Foundation (www.cambrianfoundation.org) using the best sterile technique possible given the challenging environment. The divers utilized "no mount" tank configuration, closed and semi-closed circuit re-breathers, and Nitrox gas, all in an effort to minimize their impact on the cave structure, avoid unnecessary destruction of the microbial mats, and limit oxygen and carbon dioxide bubble release into the water column. Five sampling stations were established within No-mount Cave during the January 2005 dive and visited on each subsequent date.

In addition, water samples were obtained from the main boil of Wekiwa Springs in July 2007 and from nearby groundwater wells during January 2005. The groundwater wells were located $\sim 500 \mathrm{~m}$ away from the spring pool and are maintained by the St. John's River Water Management District (Palatka, FL). The land surface at the well locations is about $20 \mathrm{~m}$ above sea level, and the cave is within a meter of sea level. For the purposes of this study, wells are referred to as "Deep" (SJRWMD ID ORO 547, which reaches the Lower Floridan aquifer; total depth: $200 \mathrm{~m}$, cased to $135 \mathrm{~m}$ ), "Mid" (ORO 548, which reaches the Upper Florian aquifer - the source of water to Wekiwa Cave according to Ferguson et al. (1947); total depth: $50 \mathrm{~m}$, cased to $30 \mathrm{~m}$ ), and "Shallow" (ORO 546; total depth: $20 \mathrm{~m}$, cased to $15 \mathrm{~m}$ ).

\section{CHEMICAL ANALYSIS}

At each station in No-mount Cave, divers collected a single large sample of water from the bulk conduit flow $(\sim 1.5 \mathrm{~L})$ for immediate analysis on the surface using a water quality sonde (Hydrolab Quanta, Loveland, $\mathrm{CO}$ ) to determine temperature $\left({ }^{\circ} \mathrm{C}\right)$, specific conductivity $(\mathrm{SpC}$, $\mathrm{mS} / \mathrm{cm}), \mathrm{pH}$, dissolved oxygen $(\mathrm{DO}, \mathrm{mg} / \mathrm{L})$, oxidationreduction potential (ORP, $\mathrm{mV}$ ), and salinity (PSS). Triplicate water samples $(250 \mathrm{~mL})$ were collected at each station for field analysis using Chemets kits (CHEMetrics, Inc., Midland, VA) to determine sulfide (Kit Catalog No. $\mathrm{K}-9510)$, iron (K-6210), ammonia (K-1510), and alkalinity (K-9810 and K-9815). Triplicate 50-mL samples were collected, filtered on the surface using a $0.2-\mu \mathrm{m}$ syringe-tip filter (Millipore, Billerica, MA), and stored frozen until laboratory analysis using a Dionex-120 Ion Chromatograph (Sunnyvale, CA) to determine the concentration $(\mathrm{mg} / \mathrm{L})$ of chloride $\left(\mathrm{Cl}^{-}\right)$, sulfate $\left(\mathrm{SO}_{4}^{2-}\right)$, nitrate $\left(\mathrm{NO}_{3}^{-}\right)$, phosphate $\left(\mathrm{PO}_{4}^{3-}\right)$, calcium $\left(\mathrm{Ca}^{2+}\right)$, sodium $\left(\mathrm{Na}^{+}\right)$, magnesium $\left(\mathrm{Mg}^{2+}\right)$, potassium $\left(\mathrm{K}^{+}\right)$, and ammonium $\left(\mathrm{NH}_{4}^{+}\right)$. An identical suite of analyses were performed on water samples from the groundwater wells and main spring boil.

\section{LABORATORY COLUMN REACTORS}

To determine the extent of the effects of abiotic sulfide oxidation on calcite dissolution, replicate columns were constructed to imitate the environmental conditions in No-mount Cave. Samples of limestone obtained as loose material from the cave floor were drained of water, air-dried, and stored dry in the laboratory for several months before being crushed using a mortar and pestle and then sieved to grain size between 0.5 and $1.0 \mathrm{~mm}$. Each column was built from a piece of $7.5-\mathrm{cm}$ diameter PVC pipe about $20 \mathrm{~cm}$ in length. The bottom of each cylinder was filled with a $10-\mathrm{cm}$-thick layer of quartz sand grains sieved as the carbonate upon which a $1.5-\mathrm{cm}$-thick layer of the crushed limestone was placed. The sand acted as a hydraulic diffuser to ensure even flow through the column, while the crushed limestone creates the interface between the groundwater within the limestone hosting No-mount Cave and the conduit water filling the cave (Fig. 2).

Artificial groundwater (Fig. 2) was prepared by dissolving analytical salts in the laboratory in proportions that yielded a chemical composition similar to that of the water flowing through the cave (Tab. 1). The $\mathrm{pH}$ of 


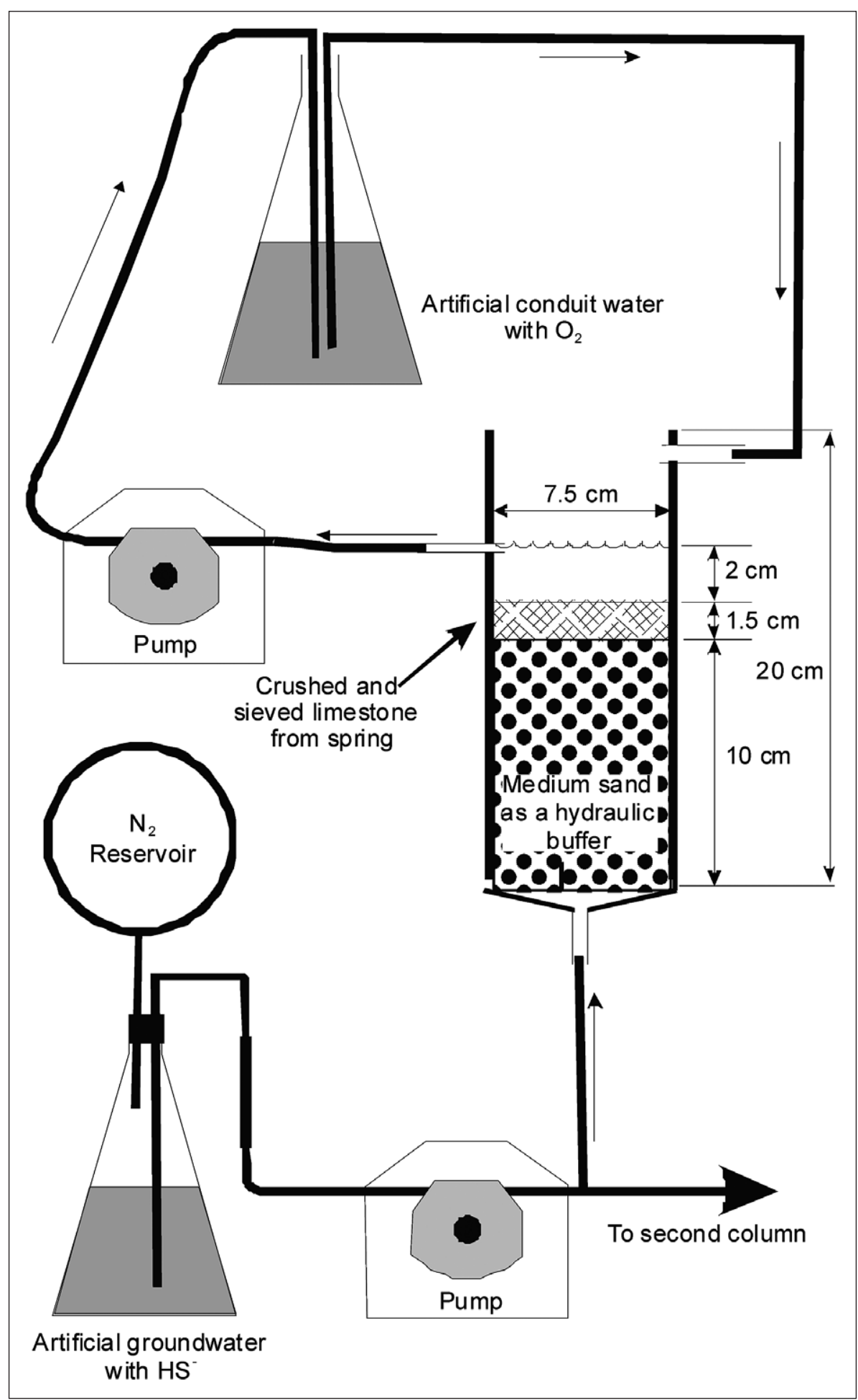

Fig. 2: Schematic of a laboratory column reactor. Artificial groundwater sparged of $\mathrm{O}_{2}$ and containing $\mathrm{HS}^{-}$flowed through the limestone layer to represent formation water, herein called groundwater. Artificial conduit water began as the same composition as groundwater except without $\mathrm{HS}^{-}$and with $\mathrm{O}_{2}$, and it was recirculated following mixing with formation water and reaction with the surface of the calcite layer.

the artificial groundwater was adjusted by small additions of strong acid or base. Laboratory temperature was similar to that in the field in Florida. In order to reduce oxygen saturation in the artificial groundwater, the solution was sparged with $\mathrm{N}_{2}$ gas to displace the oxygen, resulting in a headspace of $\mathrm{N}_{2}$ above the groundwater res- ervoir. A mylar ${ }^{\circledast}$ balloon was used to provide makeup $\mathrm{N}_{2}$ that displaced water as it was pumped from the reservoir. The resulting dissolved oxygen concentrations were low enough to accurately reflect the low oxygen concentrations observed in the groundwater in the limestone aquifer surrounding No-mount Cave. $\mathrm{Na}_{2} \mathrm{~S}$ salt was added to 
Tab. 1: The chemical composition of prepared laboratory solutions meant to simulate groundwater within the porous limestone formation and the cave-conduit water. All concentrations are reported in $\mathrm{mg} / \mathrm{L} . \mathrm{Na}_{2} \mathrm{SO}_{4}, \mathrm{NaNO}_{3}, \mathrm{NaCl}$, and $\mathrm{Na}_{2} \mathrm{~S}$ salts were used to generate the various anion concentrations, and $\mathrm{pH}$ was adjusted with $\mathrm{HCl}$ and $\mathrm{NaOH}$. Prepared without $\mathrm{Ca}^{2+}$, the waters are initially greatly undersaturated with respect to calcite.

\begin{tabular}{lllllll}
\hline & $\mathrm{Cl}^{-}$ & $\mathrm{NO}_{3}^{-}$ & $\mathrm{SO}_{4}^{2-}$ & $\mathrm{Na}^{+}$ & $\mathrm{HS}^{-}$ & $\mathrm{pH}^{-}$ \\
\hline Artificial groundwater & 4.98 & 0.573 & 16.1 & 12.1 & 0.78 & 5.37 \\
Artificial conduit water $^{2}$ & 4.97 & 0.630 & 16.2 & 11.0 & 0.0 & 8.5 \\
\hline
\end{tabular}

${ }^{1}$ Sparged with $\mathrm{N}_{2}$, so presumed $\mathrm{O}_{2}=0.0 \mathrm{mg} / \mathrm{L}$.

${ }^{2}$ In equilibrium with the atmosphere, so presumed $\mathrm{O}_{2}=9 \mathrm{mg} / \mathrm{L}$.

the artificial groundwater to achieve a dissolved HS ${ }^{-}$concentration similar to field values. In contrast, the artificial conduit water was chemically identical to the artificial groundwater except it was not sparged with $\mathrm{N}_{2}$ nor was $\mathrm{Na}_{2} \mathrm{~S}$ salt added (Tab. 1).

Groundwater (anaerobic, artificial conduit water with $\mathrm{HS}^{-}$) was pumped from its reservoir into the bottom of the column and through the sand and crushed limestone layers at a discharge rate of about $2.73 \times 10^{-2} \mathrm{~mL} / \mathrm{min}$, resulting in a 9.5 -day residence time of water in the sediment-filled portion of the column and a 30.5-hr residence time within the limestone layer. In the head space above the crushed limestone, aerobic artificial conduit water was pumped at a velocity of $3.03 \mathrm{~mL} / \mathrm{s}$ resulting in about a $2.0-\mathrm{cm}$-deep layer of water on top of the limestone layer with a residence time of about 30 seconds. Once the conduit water flowed across the surface of the limestone layer, mixed with the impinging groundwater, and flowed out of the reaction column, it was returned to the conduit-water reservoir and was subsequently recirculated.

About $50 \mathrm{~mL}$ of the simulated groundwater and conduit water were collected twice each week for four weeks. The samples were taken via a glass tube inserted into the cap covering each cave-water reservoir.

\section{CHEMICAL ANALYSIS}

The $\mathrm{pH}$, alkalinity, and $\mathrm{Ca}^{2+}$ concentration of each sample was measured within 24 hours of collection, while the remaining sample was refrigerated until further analysis. The $\mathrm{pH}$ was measured immediately upon collection using a $\mathrm{pH}$ electrode. Alkalinity was determined through the inflection-point titration method (Rounds 2006). Calcium concentrations were determined by titrating the water sample with EDTA (American Public Health Association 1995), with $0.4 \mathrm{~g} /$ titration of the crushed Erichrome Blue indicator. The anions $\mathrm{Cl}^{-}, \mathrm{SO}_{4}^{2-}$, and $\mathrm{NO}_{3}^{-}$ were determined by ion chromatography within 2 weeks of sampling. Sulfide concentrations were measured using the colorimetric method described by Otte and Morris (1994) and Cline (1969) within one week of sample collection.

\section{GEOCHEMICAL MODELING}

Calcium concentrations and alkalinity were used to determine the saturation state with respect to calcite. The chemical speciation model WATEQ4F (Ball \& Nordstrom 1991) was used to determine saturation indices for all column samples. The saturation index is an expression of degree of under- or over-saturation of an aqueous solution with respect to a mineral of interest (Langmuir 1997), where SI $<0$ indicates an undersaturated solution capable of calcite dissolution, $\mathrm{SI}=0$ indicates the solution is at equilibrium with calcite, and SI $>0$ indicates a supersaturated solution from which calcite will precipitate.

PHREEQC (Parkhurst \& Appelo 1999) is a reactionpath geochemical model based on thermodynamic data and equations for aqueous speciation and heterogeneous reactions among gas, liquid, and solid phases for calculation of the equilibrium state of a natural water of known composition with respect to various minerals. The program calculates the resulting chemical composition of aqueous solutions after two solutions mix, equilibrate with a gas phase, and equilibrate with specified minerals. In this study, PHREEQCI (Charlton \& Parkhurst 2002) was used to model a variety of scenarios, including the column system in the laboratory and the cave system in situ considering both abiotic and biotic sulfide oxidation. Although the chemistry of our laboratory and simulation experiments was actually sufficiently simplified that hand calculations might have been employed, testing the application of PHREEQCI in this report allows for building toward more complex chemical environments likely to be encountered in the field setting.

\section{Modeling the abiotic column and the abiotic cave environment}

The modeling results for the abiotic experimental column were compared to observed water compositions in order to assess the success of the model assumptions. With that success demonstrated, the subsequent modeling results for the abiotic cave system could be assumed to reasonably reflect the actual cave environment. Each scenario was entered into PHREEQCI as a series of 
Tab. 2: Steps, assumptions, and explanations for the PHREEQCI modeling simulation of the laboratory abiotic column experiment.

\begin{tabular}{|c|c|}
\hline $\begin{array}{l}\text { Step 1: Artificial groundwater in contact with calcite } \\
\text { layer }\end{array}$ & $\begin{array}{l}\text { a) Solution 1: } 1 \mathrm{~mL} \text { artificial groundwater (Tab. } 1 \text { ) } \\
\text { b) Equilibrium 1: Artificial groundwater was equilibrated with calcite } \\
\text { (i.e., } \mathrm{SI}=0) \text {. }\end{array}$ \\
\hline $\begin{array}{l}\text { Step 2: Resulting groundwater solution mixing with } \\
\text { artificial conduit water and equilibrating with an } \\
\text { oxygenated atmosphere }\end{array}$ & $\begin{array}{l}\text { a) Solution } 1 \text { saved after step } 1 \text { was used as the groundwater solution } \\
\text { b) Solution 2: } 1000 \mathrm{~mL} \text { artificial conduit water (Tab. 1) } \\
\text { c) Oxygenated atmosphere simulated with } 9 \mathrm{mg} / \mathrm{L} \text { dissolved } \mathrm{O}_{2} \text { in the } \\
\text { artificial conduit water } \\
\text { d) Mix 1: Groundwater solution and artificial conduit water mixed in } \\
\text { a ratio of } 1 \mathrm{~mL} \text { groundwater to } 1000 \mathrm{~mL} \text { conduit water. }\end{array}$ \\
\hline $\begin{array}{l}\text { Step 3: Mixed groundwater/conduit-water solution } \\
\text { allowed to react with a layer of calcite and equilibrate } \\
\text { with ambient lab } \mathrm{P}_{\mathrm{CO}_{2}}\end{array}$ & $\begin{array}{l}\text { a) Solution } 3 \text { saved after step } 2 \\
\text { b) Reaction 2: Solution } 3 \text { was reacted with } 0.2717 \text { mol calcite, as was } \\
\text { determined using the rate of calcite dissolution calculated from } \\
\text { Plummer et al. (1978), residence time in the column headspace, and } \\
\text { surface area of the calcite. } \\
\text { c) The resulting solution was equilibrated with a } \mathrm{P}_{\mathrm{CO}_{2}} \text { of } 10^{-3.3} \mathrm{~atm} \\
\text { (Jacobson \& Wu, 2009). }\end{array}$ \\
\hline $\begin{array}{l}\text { Step 4: Resulting 'circulating' conduit water allowed to } \\
\text { react with calcite layer at varying SI values based on } \\
\text { results measured from the abiotic column }\end{array}$ & $\begin{array}{l}\text { a) Solution } 4 \text { saved from step } 3 \\
\text { b) Reaction 3: calcite reacted with the solution at varying SI values. }\end{array}$ \\
\hline
\end{tabular}

steps that are outlined in Tab. 2. The amount of calcite dissolved in each reaction step was calculated using the expression for calcite dissolution rate in $\mathrm{mmol} / \mathrm{cm}^{2} / \mathrm{s}$ as a function of $\mathrm{pH}, \mathrm{Ca}^{2+}$ and $\mathrm{HCO}_{3}^{-}$concentrations, and fitted parameters published by Plummer et al. (1978).

To mimic the experimental columns using the geochemical model, the calcite dissolution rate had to be combined in a calculation using an approximate surface area of the calcite in contact with water in the experimental system and the residence time of the groundwater in the limestone layer. The residence time of the groundwater in the $1.5-\mathrm{cm}$-deep limestone layer was determined in the laboratory by timing the displacement of one pore volume through the reaction bed at the experimental pumping rate. An average grain diameter of $0.75 \mathrm{~mm}$ was used to determine the surface area of calcite in contact with the water in the $1.5-\mathrm{cm}$-deep limestone layer. It was assumed that the grains were packed closely enough that only $1 / 4$ of the surface area of calcite was exposed to dissolution. Although the selection of $25 \%$ of the surface area for reaction is a smaller value, probably by about half, than expected from calculation based on a geometric packing pattern, we chose a small value to allow for the likely hydraulic situation of incomplete access of well mixed reaction fluid to the entire physical surface area. An estimate for the total amount of calcite (in number of moles) dissolved was then calculated from the reaction rate, residence time, and exposed surface area and used in the modeling scenario.

A similar procedure was used to determine the total amount of calcite dissolved after the groundwater solution and artificial conduit water were mixed and exposed to an oxygenated atmosphere. However, the residence time was calculated for the headspace above the lime- stone layer and the surface area of calcite was approximated for the thin top layer of calcite grains in the column. It was assumed that only half of the calcite grain surface area was exposed to calcite dissolution with respect to the circulating conduit water now occupying the headspace above the calcite layer.

The modeling results were then compared to the results obtained from the circulating water in the two abiotic columns. For each column and each sampling period, a saturation index was calculated based on the measured $\mathrm{pH}$, alkalinity, and $\mathrm{Ca}^{2+}$ concentration. The saturation index obtained was then input to PHREEQCI in order to obtain theoretical values for $\mathrm{pH}$, alkalinity, and $\mathrm{Ca}^{2+}$ concentration for the corresponding time step and column. This approach allowed for a direct comparison between the results obtained from the abiotic column and the results obtained from PHREEQCI modeling.

Based on the assumptions made in the abiotic column modeling scenario and previous groundwater and conduit-water data collected from No-mount Cave, the abiotic cave environment was modeled by the steps elaborated in Tab. 3.

\section{Modeling the biotic cave environment:}

For the biotic cave environment, several different scenarios were run each using slightly different assumptions with respect to the degree of bacterially mediated sulfide oxidation. The general scenario for each model is outlined in Tab. 4, along with the variations.

Currently, no stoichiometry or rate of reaction has been formulated for sulfide-oxidizing bacteria; however, based on a series of assumptions, the amount of biological sulfide oxidation due to sulfide-oxidizing bacteria 
Tab. 3: Outline of modeling scenarios and assumptions used for the abiotic cave simulation.

\begin{tabular}{l|l}
\hline $\begin{array}{l}\text { Step 1: Groundwater in contact } \\
\text { with calcite }\end{array}$ & $\begin{array}{l}\text { a) Solution 1: Groundwater composition as defined by water samples obtained from wells in } \\
\text { the surrounding limestone aquifer (Tab. 5). } \\
\text { b) Equilibrium 1: the solution was equilibrated with a } \mathrm{P}_{\mathrm{CO}_{2}} \text { of } 10^{-2.5} \text { atm, a typical value for a } \\
\text { limestone aquifer (White, 1988). } \\
\text { c) Equilibrium 2: the solution equilibrated with the calcite cave walls ( } \mathrm{SI}=0 \text { ). It was assumed } \\
\text { that the groundwater was in contact with calcite for sufficient time to achieve } \mathrm{SI}=0 .\end{array}$ \\
\hline $\begin{array}{l}\text { Step 2: Groundwater mixing with } \\
\text { circulating conduit water }\end{array}$ & $\begin{array}{l}\text { a) Solution 1: solution obtained after the groundwater was equilibrated with calcite } \\
\text { b) Solution 2: conduit water composition as defined by measurements taken in the cave } \\
\text { system (Tab. 5). }\end{array}$ \\
& $\begin{array}{l}\text { c) Mixing 1: The mixing ratios were varied to determine the amount of groundwater needed } \\
\text { to effect calcite dissolution. }\end{array}$ \\
\hline $\begin{array}{l}\text { Step 3: Resulting circulating } \\
\text { conduit water dissolving calcite }\end{array}$ & $\begin{array}{l}\text { a) Solution 3: solution obtained after step 2 } \\
\text { b) Reaction 1: no calcite dissolution was predicted when a negative rate of reaction was } \\
\text { determined. }\end{array}$ \\
\hline
\end{tabular}

Tab. 4. Assumptions for each step in the model simulations of the biotic cave environment scenarios.

\begin{tabular}{l|l}
\hline $\begin{array}{l}\text { Step 1: Groundwater solution in } \\
\text { contact with calcite }\end{array}$ & $\begin{array}{l}\text { a) Solution 1: Groundwater composition defined by water samples obtained from wells } \\
\text { in the surrounding limestone aquifer (Tab. 5). } \\
\text { b) Equilibrium 1: solution equilibrated with calcite. It was assumed that the water was } \\
\text { in contact with calcite for sufficient time to achieve } \mathrm{SI}=0 .\end{array}$ \\
\hline $\begin{array}{l}\text { Step 2: Modeling biological } \\
\text { sulfide oxidation }\end{array}$ & $\begin{array}{l}\text { a) Three different extents of microbial sulfide oxidation were used: } \\
\text { i) High extreme: complete oxidation from sulfide to sulfate } \\
\text { ii) Low extreme: half oxidation from sulfide to sulfur granules } \\
\text { iii) Mid-scenario: all sulfide oxidized to sulfur; half sulfur oxidized to sulfate }\end{array}$ \\
\hline $\begin{array}{l}\text { Step 3: Equilibrium with calcite } \\
\text { and } \mathrm{P}_{\mathrm{CO}_{2}}\end{array}$ & $\begin{array}{l}\text { a) Equilibrium 2: resulting solution was equilibrated with calcite. It was assumed that the } \\
\text { resulting solution was in contact with the calcite for sufficient time to achieve } \mathrm{SI}=0\end{array}$ \\
\hline
\end{tabular}

was approximated. While there is no published reaction stoichiometry, the estimated energy obtained by the microorganisms during oxidation has been determined. For the partial oxidation from sulfide to sulfur, a total of $177.31 \mathrm{~kJ} / \mathrm{mol}$ is gained while the complete oxidation from sulfide to $\mathrm{SO}_{4}^{2-}$ yields a much greater energy yield of $744.49 \mathrm{~kJ} / \mathrm{mol}$ for sulfide-oxidizing bacteria found in a geothermal, limestone well in Vulcano, Italy (Amend et al. 2004). Based on the high amounts of energy obtained, assuming there is no limitation on bacterial growth, and assuming hydrogen sulfide was the limiting reagent in all reactions, all modeled scenarios oxidized hydrogen sulfide to either elemental sulfur or $\mathrm{SO}_{4}^{2-}$.

The first scenario, termed "high-extreme", assumed the bacteria would fully oxidize sulfide to $\mathrm{SO}_{4}^{2-}$ generat- ing the maximum amount of acidic protons during complete sulfide oxidation (sum of Eqns. 1 and 2). The second scenario assumed a more conservative stance where the entire sulfide concentration of the natural water was only partially oxidized to sulfur and ultimately stored in the cell as sulfur granules resulting in no production of acidic protons (Eqn. 1). The third scenario modeled was based on the combination of the two previous scenarios and observations of Thiobacillus, Thiothrix and Beggiatoa in the cave environment. In this scenario it was assumed that all sulfide in the groundwater was oxidized to elemental sulfur (Eqn. 1) and stored intracellularly as has been observed in cells acquired from No-mount Cave; then, it was assumed that half of the sulfur granules were subsequently oxidized to $\mathrm{SO}_{4}^{2-}$ (Eqn. 2).

\section{RESULTS}

The chemical composition of water collected from groundwater wells nearby, from the main boil in Wekiwa Springs, and from the conduit of No-mount Cave is reported in Tab. 5. Once these chemical data were obtained, artificial solutions representing the groundwater within the limestone formation and the conduit water in
No-mount Cave were prepared in the laboratory as described in the Methods (Tab. 1).

Monitored chemical composition of the water circulating through contact with crushed limestone and mixing with dissolved HS over a 4-week period demonstrated the feasibility of laboratory simulation of the cave 
environment and allowed an assessment of the abiotic mechanisms of calcite dissolution. Replicate laboratory columns showed calcite dissolution in the presence of abiotic sulfide oxidation and dissolution due to dissolved carbonic acid. The measured $\mathrm{HCO}_{3}^{-}$and $\mathrm{Ca}^{2+}$ (initial $\mathrm{Ca}^{2+}=0.0 \mathrm{mg} / \mathrm{L} ;$ final $\mathrm{Ca}^{2+}=9.82 \mathrm{mg} / \mathrm{L}$ ) concentrations increased over the course of the experiment. The calculated saturation state of the solution increased from an initial great undersaturation toward, but not reaching, equilibrium, indicating calcite dissolution over the entire sampling period (initial SI $=-4.0$; final SI $=-2.2$ ).

The experimental column results were compared to the output of the theoretical modeling to determine how well the assumptions made in the model reflect the physical experiment. The calculated saturation index for each sample collected from the experimental columns (from measurements of dissolved calcium and alkalinity concentrations and $\mathrm{pH}$ ) was used in the PHREEQCI simulation to determine the expected $\mathrm{pH}$, alkalinity, and calcium concentration. The agreement between measured and model-calculated parameters was generally good (e.g., Fig. 3 for $\mathrm{pH})$.

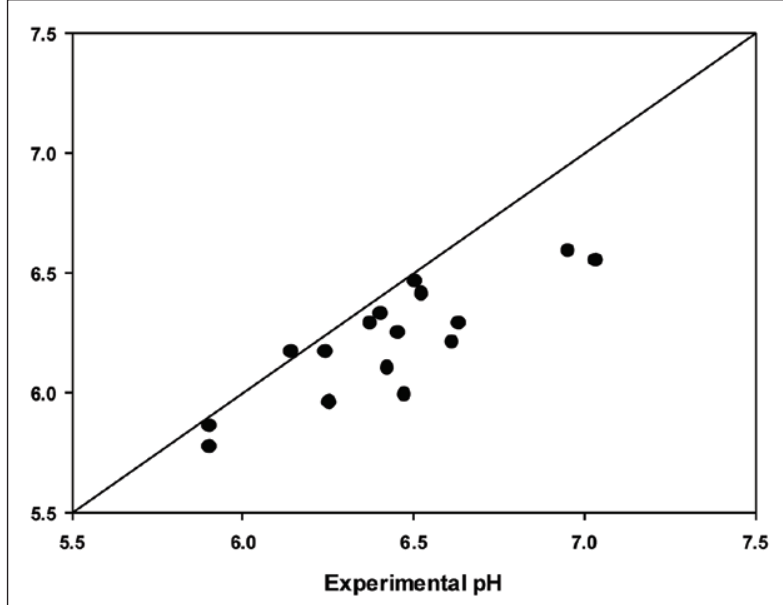

Fig. 3: Comparison between column results (experimental) and modeling results (theoretical) plotted for each value of SI, calculated from measured dissolved calcium and alkalinity concentrations, for each sampling period. $\mathrm{pH}$, a very sensitive indicator of calcite dissolution, showed good agreement between the theoretical and experimental results for both experimental columns. The line represents the 1:1 relationship, i.e., perfect agreement between experimental and theoretical results.

The abiotic cave modeling scenario indicated no dissolution would occur at the limestone wall surface due to abiotic sulfide oxidation, even when the mixing ratio between the groundwater and the cave water was unrealistically high at a volumetric ratio of 1:1. The model does indicate, however, some dissolution within the pore space due to abiotic sulfide oxidation occurring as the sulfide oxidizes in the presence of the low oxygen concentrations of the groundwater. With respect to the biotic modeling, it can be assumed that all dissolution at the groundwater-cave interface will be due to biologic, as opposed to chemical, sulfide oxidation.

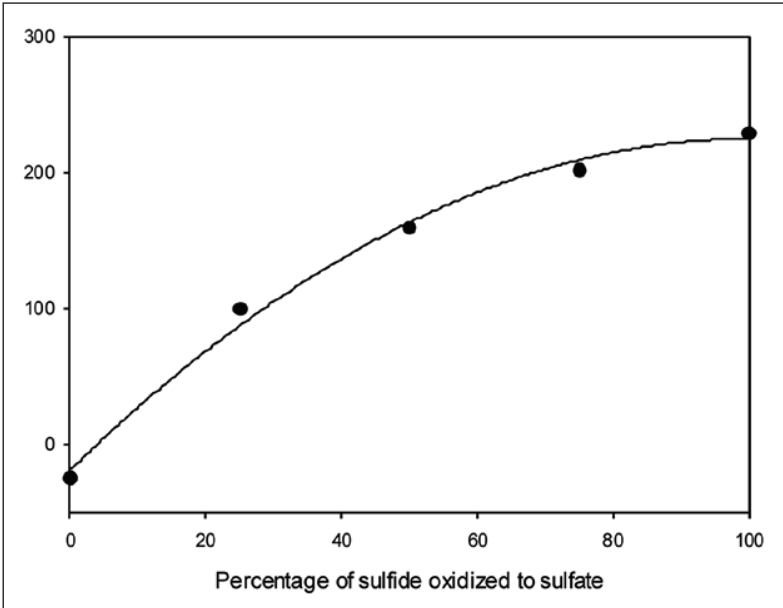

Fig. 4: The relationship between percent of biologic oxidation from sulfur to sulfate and its effect on calcite dissolution, as indicated by dissolved calcium concentration. The amount of dissolution was modeled for four different scenarios of various proportions of sulfide completely oxidizing. The calcite dissolution rate law of Plummer et al. (1978) results in an asymptotic approach to equilibrium with respect to calcite as dissolved calcium concentrations increase.

Four different scenarios were modeled to determine the percent of biological sulfur oxidation versus the amount of calcite dissolution. It was assumed that all of the dissolved sulfide was oxidized to sulfur (Eqn. 1), and, therefore, only the amount of sulfur subsequently oxidized to $\mathrm{SO}_{4}^{2-}$ (Eqn. 2) varied among the scenarios. The difference in calcium concentration between the starting solution and the modeled resultant solution was used as a proxy for the extent of calcite dissolution. A linear regression line was fit to the data and can be used to approximate the amount of calcite dissolution due to biological sulfide oxidation based on the percent of oxidation of sulfur to $\mathrm{SO}_{4}^{2-}$. The results showed a positive, linear relationship between amount of sulfide oxidation and extent of calcite dissolution (Fig. 4). Even if there was only $25 \%$ oxidation from sulfur to $\mathrm{SO}_{4}^{2-}$, about $99.4 \mathrm{mg}$ of $\mathrm{Ca}^{2+}$ would be dissolved into each $1 \mathrm{~L}$ of groundwater. 
Tab. 5: Chemical characteristics of water samples collected from Wekiwa Springs. Values are mean \pm one standard error with $N=65$ unless otherwise noted. Cells with "nd" indicate no data are available. Cells with "bdl" indicate concentrations below the detection limit.

\begin{tabular}{|c|c|c|c|c|c|}
\hline & \multicolumn{3}{|c|}{ Groundwater wells ${ }^{1}$} & \multirow{2}{*}{$\begin{array}{l}\text { Main } \\
\text { boil }^{2}\end{array}$} & \multirow[t]{2}{*}{ No-mount Cave ${ }^{3}$} \\
\hline & Deep & Mid & Shallow & & \\
\hline \multicolumn{6}{|l|}{ Sonde data } \\
\hline Temperature $\left({ }^{\circ} \mathrm{C}\right)$ & $25.3 \pm 0.0$ & $24.0 \pm 0.1$ & $24.6 \pm 0.2$ & $22.8 \pm 0.0$ & $23.6 \pm 0.2$ \\
\hline $\mathrm{SpC}(\mu \mathrm{S} / \mathrm{cm})$ & $240 \pm 0$ & $300 \pm 1$ & $300 \pm 3$ & $340 \pm 0$ & $340 \pm 18$ \\
\hline $\mathrm{pH}$ & $8.2 \pm 0.0$ & $8.1 \pm 0.0$ & $8.3 \pm 0.0$ & $7.4 \pm 0.1$ & $7.5 \pm 0.1$ \\
\hline $\mathrm{DO}(\mathrm{mg} / \mathrm{L})$ & $0.1 \pm 0.1$ & $0.4 \pm 0.4$ & $3.8 \pm 0.1$ & $4.2 \pm 0.5$ & $0.5 \pm 0.1$ \\
\hline Salinity (PSS) & $0.11 \pm 0.00$ & $0.15 \pm 0.00$ & $0.14 \pm 0.00$ & $0.18 \pm 0.00$ & $0.15 \pm 0.01$ \\
\hline $\mathrm{ORP}(\mathrm{mV})$ & $104 \pm 3$ & $199 \pm 5$ & $306 \pm 5$ & $289 \pm 4$ & $324 \pm 2$ \\
\hline \multicolumn{6}{|l|}{ Field kit data } \\
\hline Sulfide $(\mathrm{mg} \mathrm{S} / \mathrm{L})^{4}$ & $1.3 \pm 0.2$ & bdl & bdl & bdl & $\mathrm{bdl}^{5}$ \\
\hline $\begin{array}{l}\text { Alkalinity } \\
\qquad\left(\mathrm{mg} \mathrm{CaCO}_{3} / \mathrm{L}\right)\end{array}$ & nd & nd & nd & $103 \pm 6$ & $101 \pm 2$ \\
\hline Iron (mg/L) & $0.00 \pm 0.00$ & $0.02 \pm 0.02$ & $0.03 \pm 0.03$ & $0.00 \pm 0.00$ & $0.00 \pm 0.00$ \\
\hline \multicolumn{6}{|l|}{ Cations (mg/L) } \\
\hline $\mathrm{Ca}^{2+}$ & 31.0 & 35.2 & 27.2 & 39.7 & $45.3 \pm 1.3$ \\
\hline $\mathrm{Na}^{+}$ & 9.3 & 10.1 & 20.4 & 9.3 & $9.5 \pm 0.2$ \\
\hline $\mathrm{Mg}^{2+}$ & 8.6 & 9.6 & 9.7 & 11.3 & $10.2 \pm 0.2$ \\
\hline $\mathrm{K}^{+}$ & 0.4 & 0.6 & 10.4 & 1.6 & $1.4 \pm 0.0$ \\
\hline $\mathrm{NH}_{4}^{+}$ & 0.0 & 0.0 & 0.0 & 0.0 & $0.0 \pm 0.0$ \\
\hline \multicolumn{6}{|l|}{ Anions (mg/L) } \\
\hline $\mathrm{Cl}^{-}$ & 5.3 & 8.3 & 6.6 & $18.0 \pm 0.7$ & $14.2 \pm 0.3$ \\
\hline $\mathrm{SO}_{4}^{2-}$ & 15.5 & 18.6 & 29.3 & $22.1 \pm 0.8$ & $18.6 \pm 0.3$ \\
\hline $\mathrm{NO}_{3}^{-}$ & 0.1 & 0.0 & 0.3 & $0.5 \pm 0.1$ & $0.7 \pm 0.1$ \\
\hline $\mathrm{PO}_{4}^{3-}$ & 1.2 & 1.2 & 0.6 & $0.3 \pm 0.2$ & $0.4 \pm 0.0$ \\
\hline
\end{tabular}

${ }^{1}$ Sampled January 2005, N=3 per well for sonde and field kit data; $\mathrm{N}=1$ per well for cations and anions.

2 Sampled July 2007, N=3 per well for all parameters.

${ }^{3}$ Triplicate samples for each of five stations on each of the five dates $(\mathrm{N}=65)$ except for sonde data where $\mathrm{N}=25$ (one sample at each station on each date).

${ }^{4}$ The detection limit is $0.05 \mathrm{mg} \mathrm{S} / \mathrm{L}$.

${ }^{5}$ No sulfide was detected in conduit water. The limestone formation matrix water was sampled $15 \mathrm{~cm}$ deep into the cave wall rock one time within No-mount Cave at three different locations $(\sim 4,6$, and $10 \mathrm{~m}$ linear penetration distance) and yielded sulfide concentrations of $0.08,0.00$, and $0.09 \mathrm{mg} / \mathrm{L}$, respectively.

\section{DISCUSSION}

The abiotic-column modeling scenario was mainly conducted to determine if the assumptions made in the modeling could accurately reflect the evolving chemical composition of subterranean water (Fig. 1) mimicked by a physical experiment (Fig. 2). Throughout the 4-week laboratory experiment, the modeling results seemed to accurately reflect the results obtained in the in vitro columns. Based on the relatively good agreement between the experimental column results and the theoretical modeling results, we concluded that the model could be used to accurately model the cave environment. Our desire to construct laboratory columns with biological activity failed when multiple attempts to grow sulfideoxidizing bacteria from three different microbial mat samples obtained from No-mount Cave were each introduced into three different sulfide-containing growth media using standard culturing methods resulted in no growth of sulfur-granule-containing bacteria.

The abiotic cave modeling results indicate dissolution in the pore space, potentially leading to increased porosity within the limestone bedrock, but indicates no dissolution on the limestone cave-wall surface. The oxygen concentrations in the circulating cave water maybe too low to support enough abiotic sulfide oxidation to 
promote additional dissolution. In addition, the dilution factor between the incoming groundwater and the already circulating cave-water may be too high for the high sulfide and, therefore, high sulfide-oxidizing-potential groundwater to make much of an impact on the calcite-dissolving capabilities of the circulating cave water. A better estimate for abiotic oxidation could be obtained if the flux of groundwater through the entire cave-wall system and the total amount of circulating cave-water was known for the cave environment; however, the modeling, despite significantly increasing the ratio between groundwater and circulating cave water, indicates that the amount of calcite dissolution due to abiotic sulfide oxidation along the cave-wall surface will be small.

Based on the results obtained for the abiotic cave modeling, it is assumed that all oxidation on the cave wall-surface for the biotic cave modeling scenario was due to biologically mediated sulfide oxidation. Significant dissolution due to sulfide oxidation was obtained when the bacteria were modeled to oxidize all $\mathrm{HS}^{-}$to $\mathrm{SO}_{4}^{2-}$. The high amount of dissolution is expected based on the greater production of protons in the complete oxidation of sulfide (sum of Eqns. 1 and 2). From field observations, however, it seems unlikely that complete ( $100 \%$ scenario) sulfide oxidation is occurring. Intracellular sulfur granules were noted in the collected bacterial mats (Franklin et al. 2005), indicating that not all the dissolved sulfide is fully oxidized to $\mathrm{SO}_{4}^{2-}$.

On the other end of the extreme, if the microorganisms could only oxidize the sulfide to sulfur (Eqn. 1) and never produce $\mathrm{SO}_{4}^{2-}$ (Eqn. 2), the effect on extent of calcite dissolution was notable. For this scenario, no calcite was dissolved in the geochemical model simulations. This extreme, as was the case with the full sulfide oxidation, is not expected based on field observations. The $\mathrm{pH}$ of water in the micro-environments surrounding sulfuroxidizing bacterial mats has been measured as low as 0 (Hose et al. 2000; Sarbu et al. 1996). The low pH readings are attributed to the generation of acid during the biotic oxidation of sulfide at least partially to sulfate (Eqn. 2).

Consideration of these two unlikely extremes leads us to expect that the amount of $\mathrm{SO}_{4}^{2-}$ produced by sulfideoxidizing bacteria probably lies somewhere in between. From our various scenarios for simulation modeling, the assumption that all sulfide is oxidized to sulfur and subsequently only half of the sulfur is oxidized to $\mathrm{SO}_{4}^{2-}$ appears to be a reasonable approximation of field conditions. This scenario yields a concentration of $158 \mathrm{mg}$ dissolved $\mathrm{Ca}^{2+}$ per $\mathrm{L}$ of groundwater in the limestone formation. This estimate assumes the oxidized water is in contact with calcite long enough to reach equilibrium. An additional factor is the note that Acidithiobacillus has been found in the mat community as well. This organism oxidizes $\mathrm{HS}^{-}$or elemental $\mathrm{S}$ to $\mathrm{SO}_{4}^{2-}$ with the concomitant production of protons, i.e., the sum of Eqn. 1 and Eqn. 2.

In this specific modeling scenario, the mixing ratio was assumed to be 1:1000 for the groundwater and circulating conduit water, however, this assumption has not yet been corroborated with field data. More information is needed to determine the groundwater flux into the cave and the amount of circulating conduit water to more accurately predict the mixing ratio. A different mixing ratio could result in more dissolution if the groundwater flux is greater than assumed here, because it is the groundwater discharging from the porous limestone formation that contained the sulfide whose oxidation generates acidity. Conversely, there is the potential for less dissolution if the conduit water is present in large enough amounts to sufficiently dilute the acidic groundwater.

In addition, the model also assumes the acidic groundwater is in contact with the limestone wall long enough for calcite to reach equilibrium $(\mathrm{SI}=0)$. This may also be a false assumption, if the circulating cave water is moving at a rapid enough velocity to quickly and sufficiently mix the groundwater with the circulating conduit water. It may be that reaching equilibrium calcite solubility only occurs in slower-flow environments such as in pore spaces or at the microenvironment at the base of a thick biofilm. In contrast to a partial approach to equilibrium calcite dissolution, maximum biospeleogenesis will derive from sufficient contact time to allow for large amounts of calcite dissolution leading to equilibrium. More information on the physical cave environment and the structure of biofilms is needed to determine the effect that pore spaces and filamentous biofilms have on the residence time of the acidic water in contact with the conduit wall.

\section{CONCLUSION}

The results of this study indicate a strong potential for increased calcite dissolution, and ultimately cave en- largement due to sulfide-oxidizing bacteria. Based on the PHREEQCI modeling results, up to $229 \mathrm{mg}$ of calcium 
could be dissolved per square centimeter of limestone surface per liter of water, presuming complete oxidation of all available dissolved sulfide. The more conservative estimate, based on a presumed partial oxidation of the dissolved sulfide, of $158 \mathrm{mg}$ of dissolved calcium per square centimeter per liter of water is expected. Either way, the presence of sulfide-oxidizing bacteria in a limestone aquifer would indicate accelerated calcite dissolution. The study also sets groundwork for future research in the actual rate and stoichiometry for biotic sulfide oxidation, subsequent rate of calcite dissolution, and rate of cave enlargement.

\section{ACKNOWLEDGEMENTS}

The authors thank the Cambrian Foundation for local coordination and intellectual and logistical support and Florida Department of Environmental Protection for access to the springs which are located in State Parks. Fund- ing from the University of Virginia to AGH and from the National Science Foundation to RBF (DEB 0920398) is gratefully acknowledged.

\section{REFERENCES}

Amend, J.P., Rogers, K.L. \& D.R. Meyer-Dombard, 2004: Microbially mediated sulfur-redox: Energetics in marine hydrothermal vent systems.- In: Amend, J.P. et al. (eds.), Sulfur Biogeochemistry: past and present, Geological Society of America, pp. 17-34. Boulder, CO.

American Public Health Association, 1995: Standard methods for the examination of water and wastewater. American Public Health Association, Washington, D. C.

Ball, J.W. \& D.K. Nordstrom, 1991: User's manual for WATEQ4F, with revised thermodynamic data base and test cases for calculation of major, trace, and redox elements in natural waters.- U.S. Geological Survey, Open-File Report 91-183.

Bottrell, S.H., Smart, P.L., Whitaker, F. \& R. Raiswell, 1991: Geochemistry and isotope systematics of sulphur in the mixing zone of bahamian blue holes.Applied Geochemistry, 6, 97-103.

Charlton, S.R. \& D.L. Parkhurst, 2002: PHREEQCI-A graphical user interface to the geochemical model PHREEQC.- U.S. Geological Survey, Fact Sheet: FS031-02.

Cline, J.D., 1969: Spectrophotometric determination of hydrogen sulfide in natural waters.- Limnology and Oceanography, 14, 454-458.

Engel, A.S. \& K.W. Randall, 2011: Experimental Evidence for Microbially Mediated Carbonate Dissolution from the Saline Water Zone of the Edwards Aquifer, Central Texas.- Geomicrobiology Journal, 28, 4, 313-327. 10.1080/01490451.2010.500197.
Erlich, H.L. \& D.K. Newman, 2009: Geomicrobiology. CRC Press, Boca Raton, FL.

Ferguson, G.E., Lingham, C.W., Love, S.K. \& R.O. Vernon, 1947: Springs of Florida.- Florida Geological Survey, Bulletin: 31 .

Franklin, R.B., Campbell, A.H., Higgins, C.B., Barker, M.K. \& B.L. Brown, 2011: Enumerating bacterial cells on bioadhesive coated slides.- Journal of Microbiological Methods, 87, 154-160.

Franklin, R.B., Tysall, T.N., Gianotti, A. \& A.L. Mills, 2005: Geomicrobiology of phreatic caves associated with central Florida springs, Spring Meeting, American Geophysical Union, New Orleans, LA.

Hill, R.S. \& R.B. Franklin, 2012: Microbial diversity: A spatial study of microbial community assemblages in the Floridian Aquifer, 97 $7^{\text {th }}$ Annual Meeting of the Ecological Society of America, Portland, OR.

Hose, L.D., Palmer, A.N., Palmer, M.V., Northup, D.E., Boston, P.J. \& H.R. DuChene, 2000: Microbiology and geochemistry in a hydrogen-sulphide-rich karst environment.- Chemical Geology, 169, 3-4, 399-423. 10.1016/s0009-2541(00)00217-5.

Hubbard, D.A., Jr., Herman, J.S. \& P.E. Bell, 1986: The role of sulfide oxidation in the genesis of Cesspool Cave, Virginia, USA, 9th International Congress of Speleology, Barcelona, Spain, 255-257.

Jacobson, A.D. \& L. Wu, 2009: Microbial dissolution of calcite at $\mathrm{T}=28^{\circ} \mathrm{C}$ and ambient $\mathrm{pCO}_{2}$. $^{-}$Geochimica et Cosmochimica Acta, 73, 2314-2331. 10.1016/j. gca.2009.01.020. 
Langmuir, D., 1997: Aqueous Environmental Geochemistry. Prentice-Hall, Inc., Upper Saddle River, NJ, 600.

Macalady, J.L., Lyon, E.H., Koffman, B., Albertson, L.K., Meyer, K., Galdenzi, S. \& S. Mariani, 2006: Dominant microbial populations in limestonecorroding stream biofilms, Frasassi Cave system, Italy.- Applied and Environmental Microbiology, 72, 5596-5609.

Mattison, R.G., Abbiati, M., Dando, P.R., Fitzsimons, M.F., Pratt, S.M., Southward, A.J. \& E.C. Southward, 1998: Chemoautotrophic microbial mats in submarine caves with hydrothermal sulphidic springs at Cape Palinuro, Italy.- Microbial Ecology, 35, 1, 58-71.

Miller, J.A. 1986: Hydrogeologic framework of the Floridan aquifer system in Florida and in parts of Georgia, Alabama, and South Carolina.- U.S. Geological Survey Professional Paper: 1403-B.

Miller, J.A. 1990: Ground Water Atlas of the United States: Alabama, Florida, Georgia, and South Carolina.U.S. Geological Survey HA 730-G.

Otte, M.L. \& J.T. Morris, 1994: Dimethylsulphoniopropionate (DMSP) in Spartina Alterniflora Loisel.Aquatic Botany, 48, 3-4, 239-259.

Parkhurst, D.L. \& C.A.J. Appelo, 1999: User's guide to PHREEQC (Version 2)-A computer program for speciation, batch-reaction, one-dimensional transport, and inverse geochemical calculations.- U.S. Geological Survey, Water-Resources Investigations Report: 99-4259.
Plummer, L.N., Wigley, T.M.L. \& D.L. Parkhurst, 1978: Kinetics of calcite dissolution in $\mathrm{CO}_{2}$-water systems at $5^{\circ} \mathrm{C}$ to $60^{\circ} \mathrm{C}$ and 0.0 to 1.0 atm $\mathrm{CO}_{2}$.- American Journal of Science, 278, 2, 179-216.

Rounds, S.A., 2006: Alkalinity and acid neutralizing capacity (ver. 3.0), U.S. Geological Survey Techniques of Water-Resources Investigations, book 9, chap. A6, sec. 6.6. U.S. Geological Survey.

Sarbu, S.M., Kane, T.C. \& Kinkle, B.K., 1996: A chemoautotrophically based cave ecosystem.- Science, 272, 5270, 1953-1955.

Scott, T.M., 1991: A Geological overview of Florida.In: Scott, T.M. et al. (eds.), Florida's Ground Water Quality Monitoring Program- Hydrogeological Framework, pp. 5-14. Florida Geological Survey Special Publication 32.

Vlasceanu, L., Sarbu, S.M., Engel, A.S. \& B.K. Kinkle, 2000: Acidic cave-wall biofilms located in the Frasassi Gorge, Italy.- Geomicrobiology Journal, 17, 2, $125-139$.

White, W.B., 1988: Geomorphology and Hydrology of Karst Terrains. Oxford University Press, Oxford, 464 . 